$\xi=$ 囯

\title{
Subsurface mapping and geochemical investigation of a marble deposit around Igarra, Southwestern Nigeria
}

\author{
Oluwajana, O. A. *, Ogunyele, A. C., Egunjobi, K. J., Ajayi, V. A. \\ Department of Earth Sciences, Adekunle Ajasin University, P.M.B. O01, Akungba-Akoko, Ondo State, Nigeria \\ *Corresponding Author's e-mail: oladotun.oluwajana@aaua.edu.ng; abimbola.ogunyele@aaua.edu.ng
}

\begin{abstract}
Subsurface mapping of a marble deposit around Igarra and geochemical analysis of seven marble samples collected at different depths in four drill holes were carried out with the aim of determining the chemical compositions and economic viabilities of the deposit. Subsurface mapping and lithologic description revealed that snow-white and grey to dark grey marble layers occur in the four drill holes. Results of the geochemical analysis show that the $\mathrm{CaO}$ and $\mathrm{MgO}$ contents of the snow-white marble samples retrieved from depths between $10 \mathrm{~m}$ and $20 \mathrm{~m}(43.90-48.90 \mathrm{wt}$. \% and $0.19-2.35 \mathrm{wt}$. \% respectively) reflected calcitic to fairly dolomitic nature of the marble samples. This is confirmed by the high $\mathrm{CaCO}_{3}(91.65-95.75 \mathrm{wt} . \%)$ content of the samples. Grey to dark grey marble samples taken from depths between $30 \mathrm{~m}$ and $48 \mathrm{~m}$ have moderately high $\mathrm{CaO}$ contents (44.00-52.60 wt. \%) and significantly high $\mathrm{MgO}$ contents (3.50-8.70 wt. \%) which makes them highly dolomitic and impure. The pure, calcitic to fairly dolomitic marble is considered suitable as raw material for Portland cement production, flux in steel making and for paper production while the impure, dolomitic marble is suitable for making dimension stones and structural wares for landscaping purpose.
\end{abstract}

Keywords: Marble; Igarra; calcitic; dolomitic; Portland cement; subsurface mapping

\section{Introduction}

Marble is one of the most widely used mineral resources in Nigeria, especially in cement production, agriculture, construction, paint and chemical industries. Some marble deposits around Ikpeshi, Igwe, Okpella, Ubo and Obajana (all around Igarra) are presently exploited for use in the production of Portland cement, dimension stones, construction and monumental purposes while others are still being geologically appraised (Ofulume, 1993; Obasi and Anike, 2012; Elueze et al., 2015; Jimoh et al., 2016).

Data and information on the chemical composition of marble samples collected from subsurface depths around the Igarra marble deposits are scarce; hence this present study aimed at determining the chemical composition and characteristics of subsurface marble deposit around Igarra as well as identifying its economic and industrial viability. It is therefore expected that this present study would complement previous works on the development of industrial minerals in Nigeria.

\section{Location and Geological Setting}

The study area is located around Igarra, Edo State, Nigeria (Figure 1). Marble deposits around Igarra forms part of the Upper Proterozoic Igarra Schist Belt. Igarra area is underlain by rocks of the Precambrian Basement Complex of Southwestern Nigeria (Odeyemi, 1988; Rahaman, 1988). The Precambrian Basement Complex of Nigeria comprises mainly of the Migmatite-GneissQuartzite Complex, Upper Proterozoic Schist Belts and the Older Granitoids of Pan-African age (Fitches et al., 1985; Rahaman, 1988). The Nigerian Basement Complex is polycyclic in nature as it has been affected by different orogenies accompanied by deformation and metamorphism (Ajibade and Fitches, 1988; Ukaegbu, 2003; Kehinde et al., 2013).

Three major rock groups occur around Igarra: the MigmatiteGneiss Complex; a sequence of Upper Proterozoic metasediments (Igarra Schist Belt); and syn- to late-tectonic porphyritic granite, granodiorite and syenite (Figure 1) (Odeyemi, 1988; Odeyemi and Rahaman, 1992, Ocan et al., 2003). The migmatites and gneisses in the area form the basement (sensu stricto) on which the lowmedium grade metasediments of the Igarra Schist Belt were unconformably deposited and infolded.

The Igarra metasediments include quartz-biotite schist, paragneiss, marble and calc-silicate gneiss (Figure 2), polymict metaconglomerate, mica schist, phyllite and quartzite (Odeyemi, 1977, 1988; Okeke and Meju, 1985; Obasi and Anike, 2012; Jimoh et al., 2016, Adegbuyi et al., 2017). The migmatite-gneiss complex and their overlying metasediments have been intruded by intrusives (porphyritic granite, granodiorite, syenite, pegmatite and aplite) of Pan-African age $(600 \pm 150 \mathrm{Ma})$. Minor basic rocks (dolerite and lamprophyre) also intrude the metasediments in the Igarra Schist Belt.

A number of outcrops of marble associated with calc-silicate gneiss and phyllite are found in streams and rivers to the west of Igarra-Auchi road. Odeyemi $(1977,1988)$ and Jimoh et al. (2016) have suggested that the marble deposits in the Igarra Schist Belt formed as a result of metamorphism of very pure (silicate-poor) to argillaceous limestone, dolostone and/or marly protoliths coupled with migration as a result of later deformation, probably during the Pan-African age. 


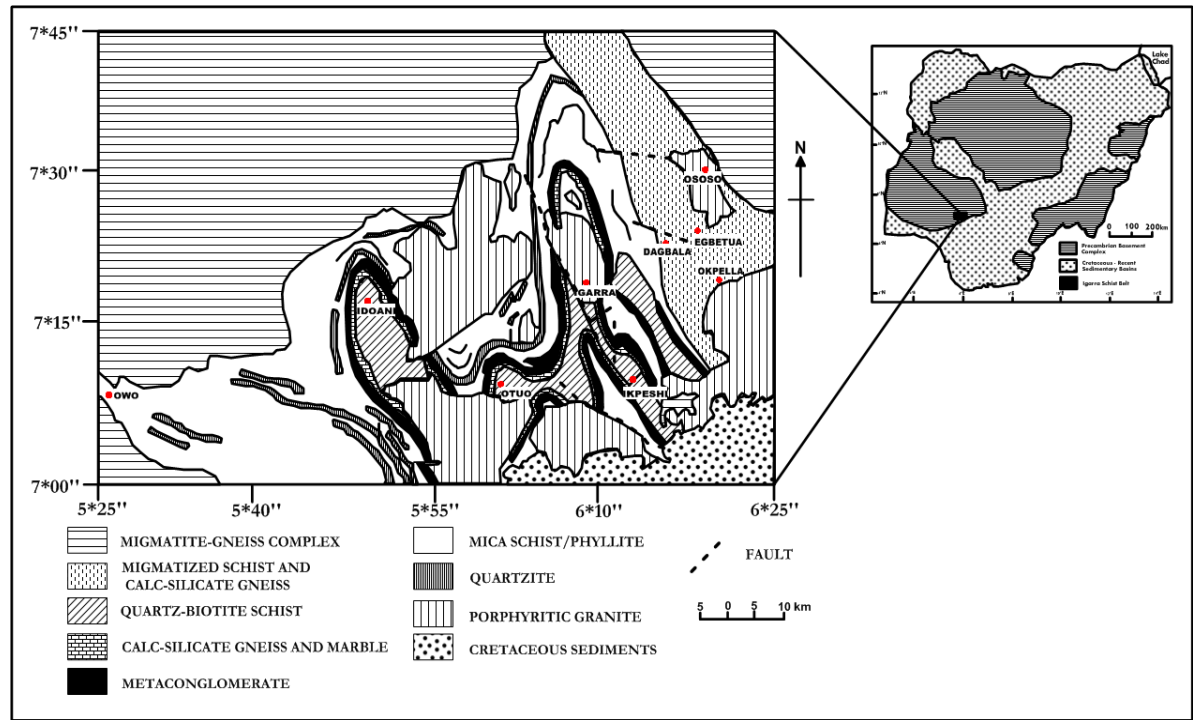

Figure 1. Geological Map of Igarra Schist Belt (inset: Geological Map of Nigeria showing Igarra Schist Belt) (adapted from Odeyemi, 1988)
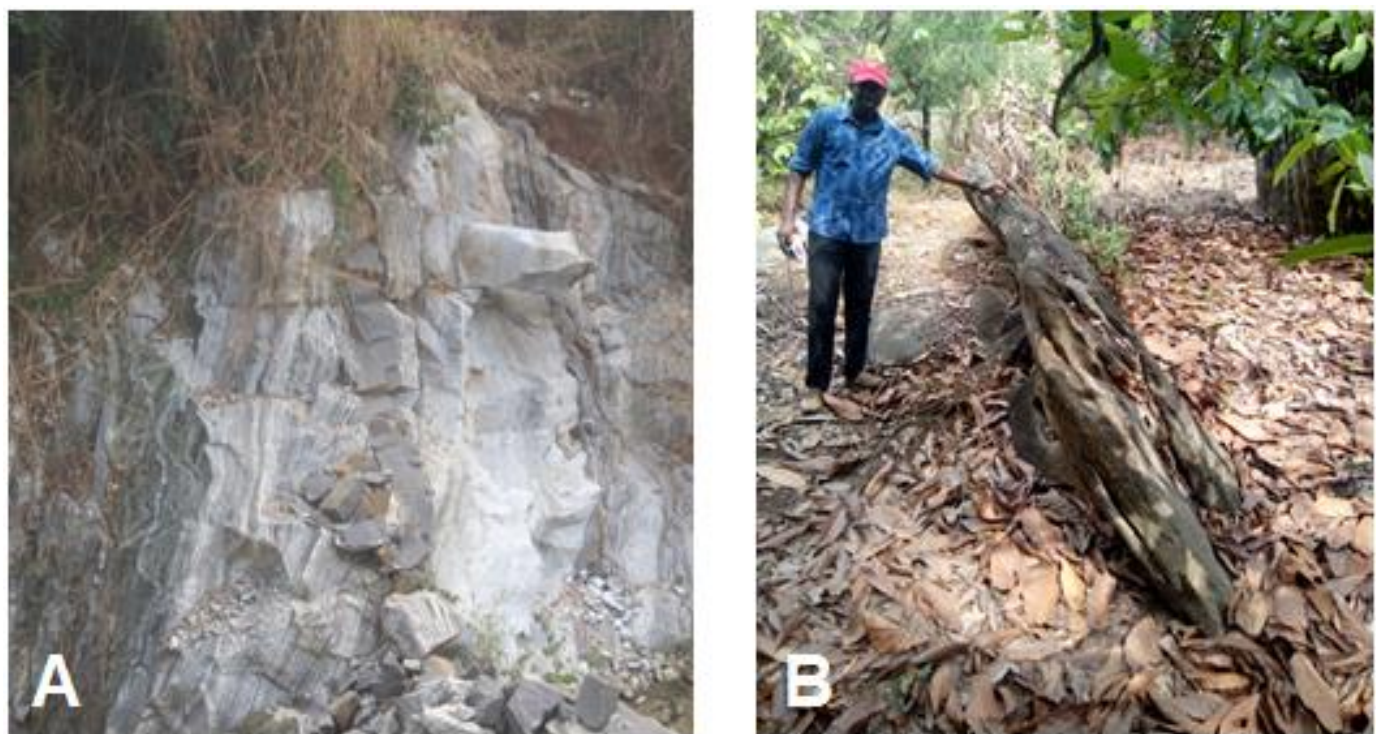

Figure 2. Pictures showing outcrop sections of (A) banded marble intruded by a dolerite dyke (dark-coloured, central, almost vertical) and (B) steeply dipping calc-silicate gneiss (located some kilometres from Igarra)

\section{Methods}

Seven (7) representative marble samples were recovered from four (4) drill holes (BH-1, BH-2, BH-3 and BH-4) (Figure 3). One marble sample was recovered from $\mathrm{BH}-1$ and two samples each from BH-2, BH-3 and BH-4 (Figure 4). The collected samples were appropriately labelled and georeferenced. Lithologic logs were generated for each drill hole. The samples were taken to the National Geosciences Research Laboratory (NGRL), Kaduna, Nigeria where they were pulverized and sieved to 200 mesh size, pressed into pellets and analysed for their major elements using Energy Dispersive X-Ray Fluorescence (ED-XRF) spectrometer (pANalytical model).

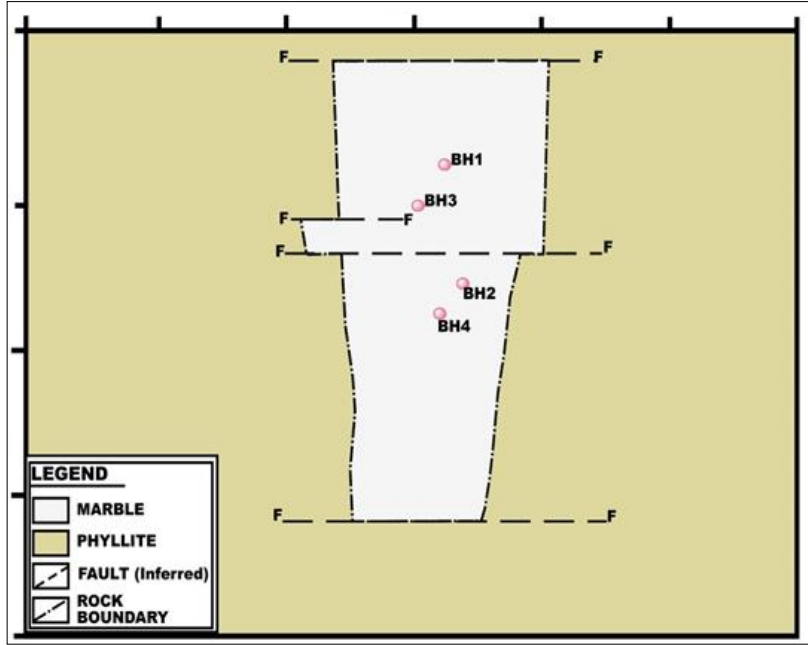

Figure 3. Map of study area showing location of drill holes $(\mathrm{BH}-1, \mathrm{BH}-$ 2, BH-3, and BH-4) within a faulted phyllitic rock body 


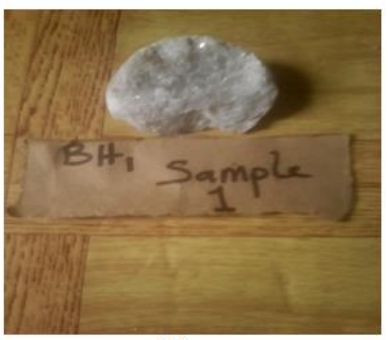

(A)



(C)

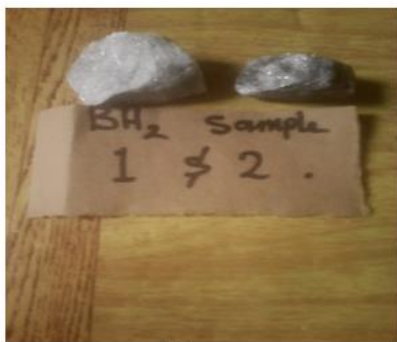

(B)

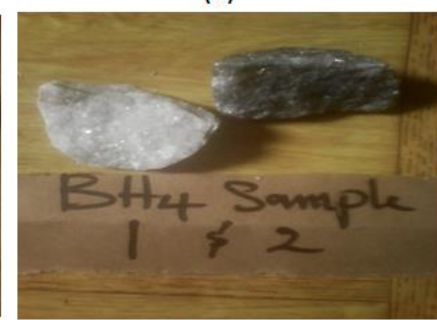

(D)
Figure 4. Marble samples recovered from BH-1 (A), BH-2 (B), BH-3 (C), and $\mathrm{BH}-4$ (D)

\section{Results}

\subsection{Lithologic Description of the Drill Holes}

The lithologic sections of the four drill holes $-\mathrm{BH}-1, \mathrm{BH}-2, \mathrm{BH}-3$ and $\mathrm{BH}-4$ are shown in Figure 5. BH-1 was drilled to a depth of about $38 \mathrm{~m}$. From the top, the rocks encountered in the drill hole (BH-1) include clayey material (10 m thick), underlain successively by unconsolidated weathered material ( $4 \mathrm{~m}$ thick), massive, white, highly crystalline and coarse grained marble ( $2 \mathrm{~m}$ thick), unconsolidated weathered material (20 m thick) and finally snowwhite coloured marble. Marble sample (IGRR_1_15) was collected from the first marble layer at a depth of $15 \mathrm{~m}$ in the hole.

BH-2 was drilled to a depth of $29 \mathrm{~m}$ and consists of a thin layer of unconsolidated weathered material $(1 \mathrm{~m}$ thick) underlain by grey marble rich in quartz (12 m thick), snow-white marble ( $3 \mathrm{~m}$ thick) and another layer of dark-grey marble. The dark grey marble layer is intruded by a thin ( $<1 \mathrm{~m}$ thick) lamprophyre sill at the top, medium-coarse grained, massive and composed largely of calcite, quartz and dolomite. One sample each was taken from the snowwhite marble (IGRR_2_15) and the dark-grey marble (IGRR_2_42) layers at depths of $15 \mathrm{~m}$ and $42 \mathrm{~m}$ respectively.

BH-3 was drilled to $53 \mathrm{~m}$ depth. The subsurface layers mapped in the hole include clayey material (7 m thick), snow-white marble (36 $\mathrm{m}$ thick) and grey coloured marble. A snow-white marble sample (IGRR_3_20) was collected from the drill hole at $20 \mathrm{~m}$ depth and another dark grey, weakly banded, grey coloured marble sample (IGRR_3_48) was retrieved at $48 \mathrm{~m}$ depth.

BH-4 is the deepest hole drilled in the area (62 m depth). The rocks mapped in the drill hole include unconsolidated weathered material ( $6 \mathrm{~m}$ thick) underlain by snow-white marble (14 m thick), grey marble rich in quartz (14 m thick), white marble ( $2 \mathrm{~m}$ thick), grey marble rich in quartz (14 $\mathrm{m}$ thick), white coloured marble (6 $\mathrm{m}$ thick) and finally by phyllite. The first grey marble and second white marble layers have been intruded by thin lamprophyre sills which are $3 \mathrm{~m}$ and $1 \mathrm{~m}$ thick respectively. Snow-white (IGRR_4_10) and grey (IGRR_4_30) marble samples were retrieved from the drill hole (BH-4) at $10 \mathrm{~m}$ and $30 \mathrm{~m}$ depths respectively.

From the lithologic sections of the marble deposit studied in the area, it is revealed that the thicknesses of the white and grey marble layers range from 2-36 $\mathrm{m}$ and $12-14 \mathrm{~m}$ respectively.

\subsection{Chemical Characteristics and Classification of the Subsurface Marble Samples}

The result of the Energy Dispersive X-Ray Fluorescence (EDXRF) analysis of the seven subsurface marble samples obtained from the four drill holes in Igarra area is presented in Table 1. The $\mathrm{SiO}_{2}$ contents of the snow-white, massive marble samples (IGRR_1_15, IGRR_2_15, IGRR_3_20 and IGRR_4_10) recovered from the four drill holes at shallow depths $(10-20 \mathrm{~m})$ ranges from 1.67-4.93 wt. \%. Their $\mathrm{CaO}$ and $\mathrm{MgO}$ contents range from 43.90-48.90 wt. \% and 0.19-2.35 wt. \% respectively which reflect the calcitic to fairly dolomitic nature of the marble samples. This is confirmed by the high $\mathrm{CaCO}_{3}$ (91.65 to 95.75 wt. \%) and LOI (42.52-48.55 wt. \%) contents of the samples. $\mathrm{Al}_{2} \mathrm{O}_{3}$ ranges from 1.94-2.60 wt. $\%$ and $\mathrm{Fe}_{2} \mathrm{O}_{3}$ from 2.10-3.73 wt. \%. Concentrations of $\mathrm{TiO}_{2}, \mathrm{MnO}, \mathrm{Na}_{2} \mathrm{O}$ and $\mathrm{K}_{2} \mathrm{O}$ are generally less than 0.50 wt. \% in all the snow-white marble samples except in IGRR_3_20 which has a $\mathrm{K}_{2} \mathrm{O}$ content of 1.26 wt. \%.

Samples IGRR_2_42, IGRR_3_48 and IGRR_4_30 collected at greater depths of $42 \mathrm{~m}, 48 \mathrm{~m}$ and $30 \mathrm{~m}$ respectively have $\mathrm{CaO}$ contents (44.00-52.60 wt. \%) comparable to the pure samples collected at shallow depths but have significantly higher $\mathrm{MgO}$ contents (3.50-8.70 wt. \%) which makes them highly dolomitic and impure. The impure nature of the marble samples is also reflected by their $\mathrm{CaCO}_{3}$ (59.88 to 68.00 wt. \%) values. The very low content of $\mathrm{CaCO}_{3}$ (59.88 wt. \%) of IGRR_2_42 which has the highest $\mathrm{CaO}$ content (52.60 wt. \%) is largely due to its high $\mathrm{MgO}$ (3.50 wt. \%), high $\mathrm{SiO}_{2}(2.90$ wt. \%) and low LOI (37.70 wt. \%) contents resulting from its high content of dolomite, quartz and other silicate minerals. The $\mathrm{SiO}_{2}\left(0.99-2.90\right.$ wt. \%) and $\mathrm{Al}_{2} \mathrm{O}_{3}$ (1.15-2.49 wt. \%) contents are fairly lower than that of the pure samples. In all the impure marble samples, $\mathrm{TiO}_{2}, \mathrm{MnO}$ and $\mathrm{Na}_{2} \mathrm{O}$ contents are generally less than 0.25 wt. \%.

Based on the percentage ratio of $\mathrm{CaO} / \mathrm{MgO}$ (Table 1), the white marble sample recovered from BH-1 (IGRR_1_15) with a $\mathrm{CaO} / \mathrm{MgO}$ ratio of 20.21 is dolomitic. Snow-white marble samples collected from BH-2 (IGRR_2_15) and BH-3 (IGRR_3_20) are calcitic (high-calcium) marble while BH-4 (IGRR_4_10) snowwhite marble sample is a calcitic (magnesian) marble. All the samples recovered from the grey-dark grey marble sections IGRR_2_42, IGRR_3_48 and IGRR_4_30 with $\mathrm{CaO} / \mathrm{MgO}$ ratios of $15.03,5.05$ and 11.33 respectively are dolomitic marbles. 

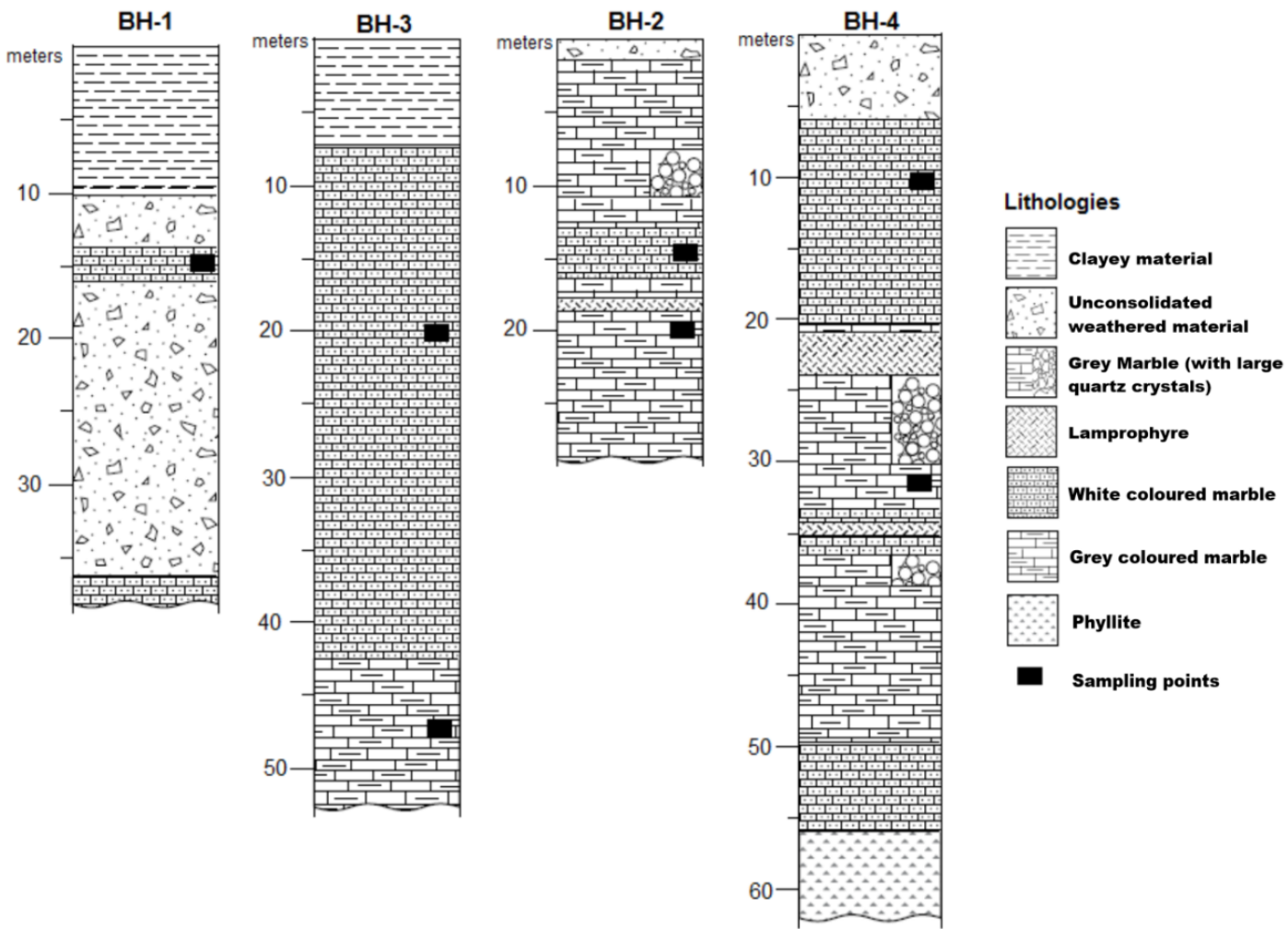

Figure 5. Subsurface profile representation of the four drill holes located around Igarra

Table 1. Major Oxide Composition of Subsurface Marble Samples recovered from four drill holes around Igarra (values in wt. \%)

\begin{tabular}{llllllll}
\hline Major Oxides & IGRR_1_15 & IGRR_2_15 & IGRR_2_42 & IGRR_3_20 & IGRR_3_48 & IGRR_4_10 & IGRR_4_30 \\
\hline $\mathrm{SiO}_{2}$ & 1.8 & 1.67 & 2.9 & 4.93 & 1.99 & 2.08 & 0.99 \\
$\mathrm{TiO}_{2}$ & 0.13 & 0.09 & 0.19 & 0.26 & 0.16 & 0.25 & 0.22 \\
$\mathrm{Al}_{2} \mathrm{O}_{3}$ & 1.99 & 2.02 & 1.7 & 2.6 & 2.49 & 1.94 & 1.15 \\
$\mathrm{MnO}$ & 0.13 & 0.07 & 0.03 & 0.42 & 0.2 & 0.17 & 0.25 \\
$\mathrm{Fe}_{2} \mathrm{O}_{3}$ & 3.64 & 3.73 & 1.57 & 2.21 & 2.65 & 2.1 & 1.57 \\
$\mathrm{MgO}$ & 2.35 & 0.19 & 3.5 & 0.55 & 8.7 & 4.01 & 4.3 \\
$\mathrm{CaO}$ & 47.5 & 48.9 & 52.6 & 44.2 & 44 & 43.9 & 48.7 \\
$\mathrm{Na} 2 \mathrm{O}$ & 0.15 & 0.08 & 0.2 & 0.17 & 0.07 & 0.04 & 0.1 \\
$\mathrm{~K}_{2} \mathrm{O}$ & 0.47 & 0.12 & 0.56 & 1.26 & 0.1 & 0.1 & 0.6 \\
$\mathrm{~L} . \mathrm{O} . \mathrm{I}$ & 42.52 & 43.33 & 37.7 & 44.01 & 39.65 & 48.55 & 41.8 \\
$\mathrm{Total}$ & 100.68 & 100.2 & 100.95 & 100.61 & 100.01 & 100.14 & 99.68 \\
$\mathrm{CaCO}$ & 95.75 & 94.28 & 59.88 & 91.65 & 61.12 & 93.31 & 68 \\
$\mathrm{CaO} / \mathrm{MgO}$ & 20.21 & 257.37 & 15.03 & 80.36 & 5.05 & 43.47 & 11.33 \\
\hline
\end{tabular}

\section{Discussion}

\subsection{Economic Applications}

Marble is a very useful raw material for a number of applications ranging from the production of cement, construction, agriculture, pharmaceutical, paint, pulp and paper to chemicals. The applicability of marble as a raw material is largely dependent on its purity, chemical composition, mineralogy, physical and engineering properties. Geochemical analysis of Igarra subsurface marble samples reveal that all the snow-white (pure, calcitic to fairly dolomitic) marble samples (IGRR_1_15, IGRR_2_15, IGRR_3_20 and IGRR_4_10) meet the specifications for the production of Portland cement according to BGS Industrial Minerals Laboratory Manual (1993) and BGS Cement Raw Materials (2005) which requires that $\mathrm{CaCO}_{3}$ content is greater than 82 wt. \%, $\mathrm{MgO}$ less than 3 wt. $\%$ and total alkalis $\left(\mathrm{Na}_{2} \mathrm{O}+\mathrm{K}_{2} \mathrm{O}\right)$ less than 0.6 wt. \%. Only IGRR_3_20 has $\mathrm{Na}_{2} \mathrm{O}+\mathrm{K}_{2} \mathrm{O}$ contents of 1.43 wt. \% which is greater than the requirement $(0.6$ wt. \%) but meets all other requirements. Hence, they are all considered suitable for Portland cement production. However, the grey to dark grey (impure, dol- omitic) marble samples collected from greater depths are unsuitable for Portland cement production because they do not meet all the requirements.

The use of marble as a flux in steel making requires that $\mathrm{SiO}_{2}$ be less than 5 wt. $\%$ (preferably < 2 wt. \%), $\mathrm{Al}_{2} \mathrm{O}_{3}$ less than 2 wt. \%, and $\mathrm{MgO}$ less than 4 wt. \% (BGS Industrial Minerals Laboratory Manual, 1993). On this basis, all the samples (both pure and impure) except IGRR_3_20 and IGRR_3_48 are considered suitable as flux in steel making.

The $\mathrm{Fe}_{2} \mathrm{O}_{3}$ content of all the marble samples (1.57-3.73 wt. \%) are too high for them be used as a flux in glass making process which requires $\mathrm{Fe}_{2} \mathrm{O}_{3}$ of a limestone or marble to be $<0.05$ wt. $\%$ and preferably $<0.02$ wt. $\%$ for colourless glass and $<0.1$ wt. $\% \mathrm{Fe}_{2} \mathrm{O}_{3}$ for coloured glass (BGS Industrial Minerals Laboratory Manual, 1993). Hence, they are not useful as a flux in glass making. For use as fillers in paints, papers and plastic production, a marble is required to have high $\mathrm{CaCO}_{3}(>96$ wt. \%) and low $\mathrm{MgO}(<1.1$ wt. \%), $\mathrm{Fe}_{2} \mathrm{O}_{3}\left(<0.25\right.$ wt. \%), $\mathrm{SiO}_{2}\left(<2.0\right.$ wt. \%) and $\mathrm{SO}_{3}(<0.1$ wt. \%) contents. Physical properties required are appropriate particle fineness, high brightness values and chemical inertness. Both the pure and impure marble do not meet all these requirements, 
however, the pure marble are more suitable than the impure variety owing to the former's high $\mathrm{CaCO}_{3}(91.65$ to 95.75 wt. \%) which is close to the requirement, low $\mathrm{MgO}$ and light colour which gives it a high brightness. The impure marble is not considered suitable as fillers in the production of paints, papers and plastic.

BGS Industrial Minerals Laboratory Manual (1993) recommends that for a marble to be used for the manufacture of carbonatebased chemical products such as calcium carbide $(\mathrm{CaC})$, calcium cyanimide, sodium carbonate, bicarbonate, hydroxide and others, it must have $\mathrm{CaCO}_{3}$ content greater than 95 wt. \%, $\mathrm{Al}_{2} \mathrm{O}_{3}+\mathrm{Fe}_{2} \mathrm{O}_{3}$ less than 0.5 wt. $\%, \mathrm{SiO}_{2}$ less than $1.2 \mathrm{wt} . \%$ and $\mathrm{P}$ in trace amount $(<0.01 \mathrm{wt} . \%)$. All the impure marble samples do not meet these requirements, hence are considered unsuitable. The pure marble samples have $\mathrm{CaCO}_{3}$ content comparable to the standard but do not meet other requirements. They may therefore need to be beneficiated before they can be used for the production of chemicals.

Lime can be produced from both the pure and impure marble varieties. The lime can be applied directly to soil for soil acidity reversal and enrichment of plant nutrients. It can also be used in the production of fertilizers.

Owing to the aesthetic (beauty) value and strength of the recovered marble samples, particularly the grey to dark grey (impure, dolomitic) variety some of which are banded and folded, they are considered suitable for the production of dimension stones and structural wares which can be used be landscaping purpose (Lai, 2001). They can also be used for sculptural and ceramic purposes as well as in construction. Other applications for which the Igarra marble, particularly the pure variety may be suitable include: water softening and treatment, water acidity reversal, sewage treatment as well as production of pesticides.

\section{Conclusion}

This present study involved subsurface mapping, lithologic description and geochemical investigation of a marble deposit around Igarra in the Southwestern Nigerian Basement Complex. Subsurface mapping and lithologic description of four drill holes indicate that snow-white and dark grey marble layers occur in the marble deposit within a faulted phyllitic rock body in Igarra area with thicknesses ranging from $2 \mathrm{~m}$ to $36 \mathrm{~m}$ and $12 \mathrm{~m}$ to $14 \mathrm{~m}$ respectively. The snow-white coloured marbles are pure calcitic to fairly dolomitic marbles while the grey to dark grey variety is highly dolomitic.

The snow-white (pure, calcitic to fairly dolomitic) marble is considered suitable as raw material for Portland cement production, flux in steel making, fillers in paints, and for paper production. The grey to dark grey (impure, dolomitic) marble which is not suitable for most of the applications of the pure variety can be used for making dimension stones and structural wares for landscaping purpose, as well as in ceramic, sculpture and as a flux material in steel making.

\section{Acknowledgement}

Authors wish to extend their profound gratitude to Geowork (Nigeria) Limited for providing the last author with subsurface marble samples and lithologic profiles of the drill holes during his industrial training attachment.

\section{References}

[1] Adegbuyi, O., Ogunyele, A. C., Odindu, M. and Erinfolami, T. G. 2017. Geochemical Characteristics and Petrogenesis of Basement Rocks in Idoani Area, Ondo State, Southwestern Nigeria. Inter. J. Adv. Geosci., vol. 5, no. 2, pp. 102-108. https://doi.org/10.14419/ijag.v5i2.8377.

[2] Ajibade, A. C. and Fitches, W. R. 1988. The Nigerian Precambrian and the Pan-African Orogeny. In: Oluyide, P. O., Mbonu, W. C., Ogezi, A. E. O., Egbuniwe, I. G., Ajibade, A. C. and Umeji, A. C. (eds.) Precambrian Geology of Nigeria. Geol. Surv. Nig., Kaduna. pp. 45-53.

[3] British Geological Survey. 1993. Industrial Minerals Laboratory Manual: Limestone. 45p.

[4] British Geological Survey Mineral Profile. 2005. Cement Raw Materials. BGS Natural Environment Research Council. 18p.

[5] Elueze, A. A., Jimoh, A. O. and Aromolaran, O. K. 2015. Compositional Characteristics and Functional Applications of Obajana Marble Deposit in the Precambrian Basement Complex of Central Nigeria. Ife J. Sci., vol. 17, no. 3, pp. 591-603.

[6] Fitches, W. R., Ajibade, A. C., Egbuniwe, I. G., Holt, R. W., Wright, J. B. (1985). Late Proterozoic Schist Belts and plutonism in Northwestern Nigeria. J. Geol. Soc. Lond., vol. 142, pp. 319-337. https://doi.org/10.1144/gsjgs.142.2.0319.

[7] Jimoh, O. A., Ariffin, K. S., Hussin, H. B., Habeeb, A. A. 2016. Characterization and assessment of Okpella Metacarbonate deposit in Nigeria. Carbonates Evaporites, pp. 1-12.

[8] Kehinde I. O., Ukaegbu V. U., Omosanya K. O., Ideozu R. U. and Mosuro G. O. 2013. Geological and geophysical mapping of fracture anisotropy at Aiyegunle and environs, Igarra area Southwestern Nigeria. J. Geol. Min. Res., vol. 5, no. 3, pp. 65-74. https://doi.org/10.5897/JGMR2013.0170.

[9] Lai, K. W. 2001. The characteristics of buried karst and its influence on foundation design in the Northwest New Territories, Hong Kong SAR. Geotech. Engr., pp. 355-360.

[10] Obasi, R. and Anike, O. L. 2012. Geochemical and Economic Application of Marble from Igarra and Ikpeshi Areas, S.W. Nigeria Inter. J. Engr. Tech., vol. 2, no. 10, pp. 1723-1727.

[11] Ocan, C. O., Coker, S. L. and Egbuniwe, I. G. 2003. The Geology of Igarra-Auchi area. Excursion guide at the Annual Conference of the Nigerian Mining and Geosciences Society (NMGS), Itakpe, $\mathrm{Ni}$ geria. $12 p$.

[12] Odeyemi, I. B. 1977. On the petrology of the Basement Complex rocks of Bendel State, Nigeria. Unpublished Ph.D. Thesis, University of Ibadan, Nigeria. 239p.

[13] Odeyemi I. B. 1988. Lithostratigraphy and structural relationships of the Upper Precambrian Metasediments in Igarra area, Southwestern Nigeria. In: Oluyide, P. O., Mbonu, W. C., Ogezi, A. E. O., Egbuniwe, I. G., Ajibade, A. C. and Umeji, A. C. (eds.) Precambrian Geology of Nigeria. Geol. Surv. Nig., Kaduna. pp. 111-125.

[14] Odeyemi, I. B. and Rahaman, M. A. 1992. The petrology of a composite syenite dyke in Igarra, Southwestern Nigeria. J. Min. Geol., vol. 28, no. 2, pp. 255-263.

[15] Ofulume, A. B. 1993. An assessment of the suitability of the Jakura marble for use as flux in steel making. J. Min. Geol., vol. 29, no. 1, pp. 1-9.

[16] Okeke, P. O. and Meju, M. A. 1985. Chemical evidence for the sedimentary origin of Igarra supracrustal rocks, Southwest Nigeria. $J$. Min. Geol., vol. 22, no. 1 and 2, pp. 97-104.

[17] Rahaman, M. A. 1988. Recent advances in the study of the Basement Complex of Nigeria. In: Oluyide, P. O., Mbonu, W. C., Ogezi, A. E. O., Egbuniwe, I. G., Ajibade, A. C. and Umeji, A. C. (eds.) Precambrian Geology of Nigeria. Geol. Surv. Nig., Kaduna. pp. 1143.

[18] Ukaegbu, V. U. 2003. The petrology and geochemistry of parts of Obudu Plateau, Bamenda Massif, Southeastern Nigeria. Unpublished Ph.D. Dissertation, University of Port Harcourt, pp. 251258 